\title{
The role of urban movements in the process of local spatial planning and the development of participation mechanism
}

\section{Abstract}

In civil societies, urban movements are one of the tools in the process of spatial governance. In Poland, urban activism is beginning to develop together with a budding participation in public life. Therefore, there is a need to assess the scope and effects of the urban movements' actions. The aim of the study was to determine and evaluate their impact on the spatial development in three Polish cities - Poznań, Gdańsk and Gdynia, especially in regard to the procedures in local urban planning and the process of participation. On the basis of the data collected during research and community interviews conducted in these cities, the following factors were analysed: the background and current profile of urban movements, the extent, regularity and effectiveness of their actions, the planning and spatial development initiatives undertaken, their cooperation with the local authorities and their contribution to the enhancement of participatory mechanisms.

Keywords

Urban movements • participation • spatial governance $\bullet$ urban planning

(C) University of Warsaw - Faculty of Geography and Regional Studies
Joanna Maria Badach ${ }^{1}$ Anna Stasiak ${ }^{2}$, Andrzej Baranowski ${ }^{3}$

'Department of Urban Architecture and Waterscapes,

Faculty of Architecture, Gdańsk University of

Technology, Gdańsk, Poland

e-mail: joanna.badach@pg.edu.pl

2Department of Environmental Design,

Faculty of Architecture, Gdańsk University of

Technology, Gdańsk, Poland

e-mail: anna.stasiak@pg.edu.pl

${ }^{3}$ Faculty of Architecture, Sopot University of Applied

Science, Sopot, Poland

e-mail: baranowskiandrzej1@gmail.com

Received: 7 March 2018

Accepted: 5 November 2018

\section{Introduction}

As important actors in the process of spatial governance, urban movements and other non-governmental organisations have been becoming increasingly active in many Polish cities in recent years. The initiatives taken by these associations to improve the quality of space and sustainable urban development are permanently changing the nature of the process of local urban planning. In view of these changes, there is a need to assess the scope and effects of the actions of urban movements, as well as their chances of becoming a stable partner in the process of urban governance. That issue has been discussed in numerous studies in its social, political and cultural dimension (see: Kowalewski 2013; Kowalewski 2016; Leontidou 2006; Novy \& Colomb 2013; Pickvance 2003; Pluciński 2014; Sowada \& Kotus 2015; Stahre 2004). However, in this work the focus was placed on spatial aspects and participatory planning.

The research concerns the impact of urban movements' activity on local urban planning and participatory mechanisms related to spatial governance. The main purpose of the paper was to present the expertise and experiences - as well as the critical opinions - of members of various urban movements on this process. It also aims to determine and critically evaluate the scope of changes to the local urban planning process caused by the actions of urban movements. The whole spectrum of urban movements' forms and modes of action in this regard was also outlined, especially in the context of the public participation process and planning procedures. This issue is especially important due to the fact that many members of urban movements are currently standing as candidates in the forthcoming municipal elections in many cities in Poland, hoping to permanently transform the way urban policy is developed.

Addressing such issues required community studies, followed by a critical analysis of the obtained results. The study was conducted in three cities - Poznań, Gdańsk and Gdynia - where various forms of urban activism have developed. The research primarily aimed to answer the following questions:

1. Within the sphere of urban activism, what are the forms and modes of action relating to the processes of both local urban planning and social participation?

2. What impact do urban movements have on the public debate on the spatial development of the city?

3. What is the scope of their cooperation with municipal authorities?

Theoretical background and explanation of concepts

City management is a very pragmatic process aimed at resolving specific problems. As Benjamin Barber points out, at city level many social, environmental and economic issues can be solved much more effectively than at national level, which may lead to a new vision of governance in a globalising world (Barber 2014). A similar view is shared by the authors of the concept of New Localism, which is a novel tool increasingly being used in solving contemporary problems based on the principles of sustainable development (Katz \& Nowak 2017). Moreover, the new model of transforming the built environment should be based on the social dimension and the active participation of residents (Badach \& Dymnicka 2017; Coaffee \& Healey 2003; García 2006). In this 
context we can perceive the city space as a "Civic Space", which is a "new perspective on the ways of managing space" both as a (...) "complex system, but also a limited good and at the same time a common value" (Baranowski 2016).

However, the concept of citizenship must be redefined in the face of social, ethnic and economic changes in contemporary cities. It has become a struggle for rights between different actors and "a dynamic institution of domination and empowerment" (Isin 2009). Therefore, local urban activism has become a new political power, incorporating Lefebvre's concept of "the right to the city" formulated back in 1967 (see Boer \& Vries 2009; Kowalewski 2016; Lefebvre 1967). Subject to numerous interpretations and criticism due to issues such as asymmetry in rights and obligations, universality and inalienability, as well as inclusiveness, it is still a popular political slogan in the fight for the empowerment of city residents (Kowalewski 2016; Pluciński 2013). According to Kowalewski (2016), urban movements can be described as a form of organised protest which derives from the sense of citizenship and the right to public activity in which improvement in the quality of life is achieved by activities within the urban space and infrastructure.

The definition of urban movements that was adopted in the article corresponds with the one given by Martínez (2011). He refers to urban movements as an institutionalised and permanent form of grassroots activism, defined as a very diverse network of organisations and social groups involved in the process of spatial planning and urban policy-making, often outside the formal institutional framework. Their role should not be confined to criticism and claims against the authorities (de Souza 2006), as can be seen in the case of "NIMBY" organisations (Not In My BackYard), which base their actions on opposition to new master plans or changes in the use of urban areas (McClymont \& O'Hare 2008). The activity of urban movements should primarily manifest in proposing and implementing alternative solutions based on their understanding of local social, cultural and spatial conditions as well as technical or academic knowledge (de Souza 2006). Thus, if local authorities fail to effectively manage a city through the active participation of residents, this gap may be filled by the phenomenon of urban activism.

Urban movements should be considered within the broader theoretical framework of urban transformation and activism in recent decades. The neoliberalisation of the city in the 1980s, and growing urban problems such as poverty, unemployment and housing needs, led to local authorities taking an interest in innovative solutions in local planning and urban governance. This caused a shift from antagonistic relations to a cooperation between the authorities and various urban movements (Mayer 2013). The economic and political changes which characterise rapid contemporary urbanisation have triggered various forms of collective civic activism aimed at tackling both social and spatial issues, as well as the environmental erosion of the city (Monno 2016). Moreover, new types of political subjects that had previously been excluded from civil rights and the institutional channels to voice their claims have become included in the phenomenon of urban activism. Referred to as "undocumented urban activism", this process increasingly often takes place among illegal and often invisible immigrants inhabiting the city informally (Swerts 2017). However, the main focus of the article is placed on institutionalised urban movements and their role in the process of local urban planning and social participation, and on their cooperation with local authorities.

The re-emergence of grassroots activism in Central and Eastern Europe was the results of the transition from a statecontrolled reality to a more diverse and liberal civil society. This phenomenon has taken many different forms over the period of political and economic transformation: reformed organisations from the former system, non-governmental organisations (NGOs), local grassroots activism and momentary mobilisations referring to current issues and publicised on social media and the Internet (Jacobsson 2015). In Poland, the crucial breakthrough for urban activism took place in 2011 when the first edition of participatory budgeting was held in Sopot and when the Congress of Urban Movements (Kongres Ruchów Miejskich), which is an alliance of urban movements from various cities was established (Grabkowska 2018). Nowadays, we can observe a growing interest in urban activism among residents in Polish cities (Kowalewski 2016). Initially emerging as local neighbourhood activities, it has developed into a new organisational form, providing specific solutions to local problems, developing democratic mechanisms at a local scale and coming up with novel ideas, norms and models of the city (Domaradzka \& Wijkström 2016). The existence of urban activism is also noted outside institutionalised organisations, but this informal civic activism is very difficult for researchers to capture (Polanska 2018).

\section{Materials and methods}

In the study, qualitative techniques were used, a key part of which were free-form interviews conducted with members of established urban movements from Poznań, Gdańsk and Gdynia, social experts and individual activists, in order to obtain a wider overview of the phenomenon. The urban movements selected for the study represent different profiles, strategies, scales of action and approaches to urban, infrastructural or social issues. The group included both strictly urban-planning, expert organisations and sociopolitical organisations, whose common factor was some interest in planning and spatial issues. Their visibility and recognisability among recipients is also varied. Such a study group made it possible to obtain a representative sample and to showcase the great diversity in the community of urban activists and to note many aspects connected with such activities. However, it is important to note that the qualitative research was preliminary in character. The interviews were supplemented by extensive collection of data on the activity of urban movements in the Tri-City and Poznań, as well as on the proposed vision for spatial development. This included generally available data from the discussed urban movements' websites, social media posts and blogs, as well as articles or interviews relating to them in local newspapers, in addition to data obtained directly from the members of the social movements (such as annual reports on their activities).

Eleven free-form interviews were conducted in the period from July 2017 to February 2018 in Poznań, Gdańsk and Gdynia. Only a general plan and the scope of issues to be discussed during the interviews were formulated beforehand. This particular method was chosen since its use makes it possible to obtain in-depth information concerning the actions of the interviewed associations as well as the opinions of people involved in the researched phenomenon (Lewandowska 2004). The researchers were equipped with a standardised list of all the information sought, which was based on an extensive background query and observations, but they adapted the course of the interview according to the individual answers of the interviewed people (as described by Konecki 2005). The instruction for the free-form interviews is available as an annex to this article (Annex 1).

During the interviews, the respondents were asked mainly about the circumstances of the inception, scope, scale, regularity and methods of action of urban movements in a given city, their substantive development, their target groups and the problems addressed, as well as the increase in spatial awareness of the residents and cooperation with the city authorities. The list of free interviews and their codes, as well as the summary of selected information concerning interviewed members of urban movements, activists and experts, is presented in Tables 1-3. All conversations were audio-recorded, then transcribed. The 
Table 1. Compiled selected data on urban movement members, city activists and social experts from Poznań with whom free-form interviews were conducted. Source: own elaboration based on free-form interviews.

\begin{tabular}{|c|c|c|c|c|c|c|c|c|c|}
\hline Code & $\begin{array}{c}\text { Date of } \\
\text { interview }\end{array}$ & $\begin{array}{l}\text { Name of } \\
\text { association }\end{array}$ & $\begin{array}{c}\text { Name of } \\
\text { interviewee }\end{array}$ & $\begin{array}{l}\text { Function in } \\
\text { association/ } \\
\text { Occupation }\end{array}$ & Founded & Founder & Profile & $\begin{array}{l}\text { Number of } \\
\text { members }\end{array}$ & $\begin{array}{c}\text { Number of } \\
\text { members } \\
\text { trained in } \\
\text { architecture, } \\
\text { urban } \\
\text { planning } \\
\text { or spatial } \\
\text { planning- } \\
\text { related }\end{array}$ \\
\hline PZ01 & $\begin{array}{c}28 \\
\text { October } \\
2017\end{array}$ & $n / a$ & Jakub Głaz & $\begin{array}{l}\text { Architect, } \\
\text { architecture } \\
\text { critic and } \\
\text { publicist }\end{array}$ & 2006 & $n / a$ & $n / a$ & $n / a$ & $n / a$ \\
\hline PZ02 & $\begin{array}{c}9 \\
\text { December } \\
2017\end{array}$ & $n / a$ & $\begin{array}{c}\text { Maciej } \\
\text { Frąckowiak }\end{array}$ & $\begin{array}{l}\text { Sociologist, } \\
\text { academic and } \\
\text { publicist }\end{array}$ & $n / a$ & $n / a$ & $n / a$ & $n / a$ & $n / a$ \\
\hline PZ03 & $\begin{array}{c}9 \\
\text { December } \\
2017\end{array}$ & $\begin{array}{c}\text { The Anarchist } \\
\text { Federation } \\
\text { (Federacja } \\
\text { Anarchistyczna) }\end{array}$ & $\begin{array}{c}\text { Marek } \\
\text { Piekarski }\end{array}$ & $\begin{array}{l}\text { Member of } \\
\text { the Anarchist } \\
\text { Federation } \\
\text { in Poznań, } \\
\text { member of } \\
\text { the Rozbrat } \\
\text { collective }\end{array}$ & 1988 & $n / a$ & $\begin{array}{l}\text { the activity } \\
\text { concerns } \\
\text { issues } \\
\text { ranging from } \\
\text { cycling routes } \\
\text { through } \\
\text { tenant issues } \\
\text { to legal } \\
\text { issues }\end{array}$ & $\begin{array}{l}\text { about } 40 \\
\text { persons at } \\
\text { meetings; } \\
\text { about } 150 \\
\text { persons at } \\
\text { organised } \\
\text { actions. }\end{array}$ & $n / a$ \\
\hline PZ04 & $\begin{array}{c}9 \\
\text { December } \\
2017\end{array}$ & $\begin{array}{c}\text { The Right to the } \\
\text { City (Prawo do } \\
\text { Miasta) }\end{array}$ & $\begin{array}{l}\text { 1. Lech } \\
\text { Mergler } \\
\text { 2. Tomasz } \\
\text { Wierzbicki }\end{array}$ & $\begin{array}{l}\text { 1. Vice } \\
\text { chairman of the } \\
\text { association, } \\
\text { Chairman of } \\
\text { the Congress } \\
\text { of Urban } \\
\text { Movements, } \\
\text { publicist } \\
\text { 2. Member of } \\
\text { the Poznan } \\
\text { City Council, } \\
\text { member of the } \\
\text { association }\end{array}$ & 2013 & $\begin{array}{l}35 \text { members } \\
\text { previously } \\
\text { involved } \\
\text { in the } \\
\text { association } \\
\text { We } \\
\text { Poznanians } \\
\text { (My- } \\
\text { Poznaniacy) }\end{array}$ & $\begin{array}{c}\text { an expert } \\
\text { organisation } \\
\text { supporting } \\
\text { the city in } \\
\text { decision- } \\
\text { making }\end{array}$ & about 50 & $\begin{array}{l}\text { several: a } \\
\text { dozen or so }\end{array}$ \\
\hline
\end{tabular}

collected material was then subjected to coding. Due to their complex structure and great diversity, segments of the transcribed statements were divided into thematic categories (as decribed by Babbie 2007), taking into account the predefined research questions. As a result of the analysis of the qualitative material, the most important findings regarding each city were collated and compared. On that basis, the structure of this article was defined and the results and conclusions were formulated. In the results section, different aspects of urban movements' activities, and the experiences and opinions expressed directly by interviewees, were presented. In the conclusions and discussion section, these findings were subjected to critical analysis, and directions for further research were outlined.

Results: specification of urban movements in Poznań, Gdańsk and Gdynia

Urban movements in Poznań

Urban activism in Poznań began much sooner than in Gdańsk or Gdynia and it can be stated that it was initiated by the anarchist movement in the 1990s (PZ03), when a group of anarchists established a squat called Rozbrat in 1994 as a form of bottom-up protest against the free market economy and the neoliberalisation of the city (see Rosochacka 2017). At some point, the members of the middle class started to get involved in some of the anarchists' protests, especially concerning spatial and planning issues, e.g. the Study of Conditioning and the Directions of Land Use Planning for the City of Poznań. Over 500 remarks were submitted to its project; however, they were mostly ignored by the authorities. Increasing numbers of people started to gather around this conflict and one of the first institutionalised urban movements in Poznań (called "We Poznanians" [My Poznaniacy]) emerged in 2007 from that co-operation (PZ03). Over the years, more associations and neighbourhood councils were created, e.g. "Investments for Poznań" (Inwestycje dla Poznania) (PZ01), and the initial one split, with some of its members establishing a new association called "The Right to the City" (Prawo do Miasta), whose members were interviewed during the study. Another very important part of the process of urban activism in Poznań was 
Table 2. Compiled selected data on urban movement members, city activists and social experts from Gdańsk with whom free-form interviews were conducted. Source: own elaboration based on free-form interviews

\begin{tabular}{|c|c|c|c|c|c|c|c|c|c|}
\hline Code & $\begin{array}{c}\text { Date of } \\
\text { interview }\end{array}$ & $\begin{array}{l}\text { Name of } \\
\text { association }\end{array}$ & $\begin{array}{c}\text { Name of } \\
\text { interviewee }\end{array}$ & $\begin{array}{l}\text { Function in } \\
\text { association/ } \\
\text { Occupation }\end{array}$ & Founded & Founder & Profile & $\begin{array}{c}\text { Number } \\
\text { of } \\
\text { members }\end{array}$ & \begin{tabular}{|c|} 
Number of \\
members \\
trained in \\
architecture, \\
urban planning \\
or spatial \\
planning- \\
related \\
\end{tabular} \\
\hline GDA01 & $\begin{array}{l}12 \text { June } \\
2017\end{array}$ & $\begin{array}{l}\text { The Gdańsk } \\
\text { Agglomeration } \\
\text { Development } \\
\text { Forum (Forum } \\
\text { Rozwoju } \\
\text { Aglomeracji } \\
\text { Gdańskiej } \\
\text { FRAG) }\end{array}$ & $\begin{array}{l}\text { 1. Karol } \\
\text { Spieglanin } \\
\text { 2. Marta } \\
\text { Gibczyńska } \\
\text { 3. Paweł } \\
\text { Mrozek } \\
\text { 4. Jarosław } \\
\text { Paczos }\end{array}$ & $\begin{array}{l}\text { 1. Chairman of the } \\
\text { association } \\
\text { 2. Secretary of the } \\
\text { association } \\
\text { 3. Vice chairman } \\
\text { of the association, } \\
\text { academic } \\
\text { 4. Vice chairman } \\
\text { of the association }\end{array}$ & $\begin{array}{c}2009 \\
\text { (informally } \\
2006 \text { ) }\end{array}$ & $\begin{array}{c}\text { Maciej } \\
\text { Suchanek }\end{array}$ & $\begin{array}{c}\text { public benefit } \\
\text { organisation } \\
\text { focused on } \\
\text { urban spatial } \\
\text { policy issues } \\
\text { in order to } \\
\text { promote } \\
\text { sustainable } \\
\text { development. }\end{array}$ & $\begin{array}{c}\text { about } 30 \\
\text { registered; } \\
\begin{array}{c}15-20 \\
\text { active }\end{array}\end{array}$ & $30 \%$ of members \\
\hline GDA02 & $\begin{array}{c}18 \text { October } \\
2018\end{array}$ & $\begin{array}{l}\text { The City } \\
\text { Initiative } \\
\text { (Inicjatywa } \\
\text { Miasto) }\end{array}$ & Piotr Czyż & $\begin{array}{l}\text { Chairman of } \\
\text { the association, } \\
\text { academic }\end{array}$ & 2013 & Piotr Czyż & place-making & \begin{tabular}{|c|}
$4-5$ \\
permanent \\
members; \\
\\
about 15 \\
external \\
persons
\end{tabular} & 15 \\
\hline GDA03 & 2 July 2018 & $\mathrm{n} / \mathrm{a}$ & $\begin{array}{l}\text { Katarzyna } \\
\text { Szczepańska }\end{array}$ & $\begin{array}{l}\text { member of the } \\
\text { Wrzeszcz district } \\
\text { council, co- } \\
\text { founder of the } \\
\text { Wrzeszcz digital } \\
\text { museum } \\
\end{array}$ & $\begin{array}{l}2004 / \\
2005\end{array}$ & $n / a$ & $n / a$ & $n / a$ & $\mathrm{n} / \mathrm{a}$ \\
\hline GDA04 & $\begin{array}{c}9 \text { November } \\
2017\end{array}$ & $\mathrm{n} / \mathrm{a}$ & $\begin{array}{c}\text { Lidia } \\
\text { Makowska }\end{array}$ & $\begin{array}{l}\text { Local activist, } \\
\text { member of } \\
\text { the Wrzeszcz } \\
\text { district council, } \\
\text { member of the } \\
\text { Better Gdańsk } \\
\text { association }\end{array}$ & 2007 & $\mathrm{n} / \mathrm{a}$ & $\mathrm{n} / \mathrm{a}$ & $\mathrm{n} / \mathrm{a}$ & $\mathrm{n} / \mathrm{a}$ \\
\hline GDA05 & $\begin{array}{c}7 \\
\text { September } \\
2017\end{array}$ & $\begin{array}{l}\text { A Better } \\
\text { Gdańsk } \\
\text { (Lepszy } \\
\text { Gdańsk) }\end{array}$ & $\begin{array}{c}\text { Jędrzej } \\
\text { Wlodarczyk }\end{array}$ & $\begin{array}{l}\text { Member of } \\
\text { the Siedlce } \\
\text { district council, } \\
\text { member of the } \\
\text { Better Gdańsk } \\
\text { association board }\end{array}$ & 2014 & $\begin{array}{l}\text { Jolanta } \\
\text { Banach }\end{array}$ & \begin{tabular}{|c|} 
political \\
association \\
but not party \\
non-expert \\
association; \\
activities \\
related to \\
local politics, \\
social life, \\
investment, \\
etc.
\end{tabular} & about 40 & 3 \\
\hline
\end{tabular}

the discussion about the inner-city revitalisation programme that was initialised in late 2010 to early 2011 by one of the members of the city council and led to strong co-operation between various actors and a series of public debates on the subject (PZO1).

Nowadays, the scale of the action undertaken by urban movements is usually local, and concerns particular projects and initiatives, e.g. the public discussion about the redevelopment of
Głogowska Street in Poznań, which was also a very successful participatory project (PZ01). The aim of this initiative was to calm road traffic and to convert one of the traffic lanes in each direction to pedestrian and cycling use. Moreover, it was advocated that more green spaces and pedestrian infrastructure be created, and the tram line and stops were redeveloped (Nowa Głogowska 2018). However, although the issues tackled by the urban movements 
Table 3. Compiled selected data on urban movement members, city activists and social experts from Gdynia with whom free-form interviews were conducted. Source: own elaboration based on free-form interviews

\begin{tabular}{|c|c|c|c|c|c|c|c|c|c|}
\hline Code & $\begin{array}{c}\text { Date of } \\
\text { interview }\end{array}$ & $\begin{array}{c}\text { Name of } \\
\text { association }\end{array}$ & $\begin{array}{c}\text { Name of } \\
\text { interviewee }\end{array}$ & $\begin{array}{l}\text { Function in } \\
\text { association/ } \\
\text { Occupation }\end{array}$ & Founded & Founder & Profile & $\begin{array}{c}\text { Number of } \\
\text { members }\end{array}$ & $\begin{array}{c}\text { Number of } \\
\text { members } \\
\text { trained in } \\
\text { architecture, } \\
\text { urban } \\
\text { planning } \\
\text { or spatial } \\
\text { planning- } \\
\text { related }\end{array}$ \\
\hline GDY01 & $\begin{array}{c}15 \\
\text { September } \\
2017\end{array}$ & $\begin{array}{c}\text { The Common } \\
\text { City (Miasto } \\
\text { Wspólne) }\end{array}$ & Szymon Jaros & $\begin{array}{l}\text { Member of the } \\
\text { association } \\
\text { board }\end{array}$ & 2016 & $\begin{array}{c}\text { Łukasz } \\
\text { Piesiewicz }\end{array}$ & $\begin{array}{c}\text { non-profit } \\
\text { organisation } \\
\text { working for } \\
\text { sustainable } \\
\text { transport and } \\
\text { harmonious } \\
\text { spatial } \\
\text { development of } \\
\text { Gdynia }\end{array}$ & about 20 & several \\
\hline GDY02 & $\begin{array}{l}1 \text { January } \\
2018\end{array}$ & $\begin{array}{c}\text { Cycling } \\
\text { Gdynia } \\
\text { (Rowerowa } \\
\text { Gdynia) }\end{array}$ & $\begin{array}{c}\text { Kajetan } \\
\text { Lewandowski }\end{array}$ & $\begin{array}{l}\text { Chairman of the } \\
\text { association }\end{array}$ & 2010 & $\begin{array}{l}\text { Jakub } \\
\text { Furkal and } \\
\text { Łukasz } \\
\text { Bosowski }\end{array}$ & $\begin{array}{c}\text { initially a } \\
\text { protesting } \\
\text { and radical } \\
\text { organisation; } \\
\text { presently they act } \\
\text { as an expertise } \\
\text { and logistics } \\
\text { group }\end{array}$ & about 10 & none \\
\hline
\end{tabular}

usually related to the local and neighbourhood scale, they were successfully placed in the context of the entire city (PZ01). Moreover, the "Right to the City" association is also actively involved in activities beyond the city scale, being one of the founders of the "Congress of Urban Movements". They created the so-called "City-view" (Miastopogląd) in the form of 15 Urban Theses, which is now the statute of the congress (Kongres Ruchów Miejskich 2018a). They have also undertaken some publicist work and created a manual for urban activists in Polish cities (see Mergler et al. 2013).

Specific activities connected with spatial planning range from submitting proposals and remarks to local spatial development plans, through raising awareness of spatial and planning issues among residents (PZO4), commenting on transportation plans and urban development strategies and being consulted on environmental decisions regarding new investments, to participating in public consultations and debates (PZ01, PZ04). They have successfully protested against some poorly-devised municipal plans, e.g. concerning Sołacki Park and the area adjacent to the Szyc Stadium (PZ04). In the former case, the issue relates to a conflict between the municipal authorities, urban activists and a private developer who intended to build a residential development in the area adjacent to the park. The proposed local land-use plan also received a negative recommendation from the municipal committee for urban planning (Łukaszewski 2016). In the case of the stadium, the right of perpetual usufruct for the area was sold to a private investor, but residential development was not allowed in the local land-use plan. Finally, the area returned to the municipality and, after being revitalised, will serve as a sports and recreation area for the inhabitants (GW 2018). It was noted that such changes are possible due to the fact that urban movements in Poznań are very strong (including intellectually) and recognisable, and so are capable of framing the public discourse (PZ02). However, the message of that discourse is usually received by those whose awareness is already well-developed (PZ01), and reaching the group of people who remain uninterested in spatial issues is extremely difficult and requires a lot of work and knowledge (PZ04). It was also stressed in the interviews that co-operation with the municipality in the area of local urban planning has significantly improved over recent years (PZ01) and some urban activists have gone on to become a part of the local authorities (PZ04). A view was also expressed that although people seek more participation in the governance of the city, they still have very little impact on this process. Moreover, resident levels of trust towards city officials is still very low (PZO3).

\section{Urban activism in Gdańsk}

In Gdańsk the formation of urban movements was preceded by the activities of various local associations that existed primarily as social organisations, but only at the turn of 2008 developed awareness of spatial issues and discovered their potential in this field. These were the "Orunia Association of Local Initiatives" (Stowarzyszenie Inicjatyw Lokalnych Orunia) and the "Gdańsk Network of Local Partnerships" (Gdańska Sieć Partnerstw Lokalnych) (GDA04). Cyclist groups were also one of the first to start some initiatives and public debates on spatial and infrastructural development, for example the "Cycling Gdańsk" association (Rowerowy Gdańsk) (GDA03). Officially, The Gdańsk Agglomeration Development Forum (Forum Rozwoju Aglomeracji Gdańskiej [FRAG]) was the first urban movement to be established in Gdańsk, in 2009. Its members were interviewed during the research. In the following years more associations were established, including the following two, which were also 
subjects of the research: The City Initiative (Inicjatywa Miasto) and A Better Gdańsk (Lepszy Gdańsk).

In the case of FRAG, their activity was primarily aimed at supporting certain projects undertaken by the city, and the attitude of this association was initially strictly pro-investment-oriented. However, after some time its members started to be more critical of some investments. Nowadays, some members deal with issues connected with spatial planning, at the level of both planning and implementation, and some work as city officials (GDA01). The City Initiative association was established to facilitate a social movement called "Project for Public Spaces" (PPS) in which public space is shaped for the residents and with their participation - an approach often called "place-making" (GDA02). PPS was developed by a non-profit organisation and was aimed at helping local communities to create and sustain their public spaces. Place-making has been defined as a philosophy and a practical process for transforming these spaces. It consists of five phases: defining the place and the identity of the stakeholders, evaluating space and identity issues, creating space vision, performing short-term experiments and, finally, re-evaluating and performing long-term improvements (PPS 2018). This initiative and the chosen mode of action were caused by the founders' irritation at the lack of action in public space and the inefficiency of participation in Gdańsk. In numerous previous cases the ideas and opinions of the residents remained unimplemented in municipal projects and a majority of public initiatives ended without any tangible effect (GDA02). A Better Gdańsk, on the other hand, was established as a non-expert association related to local policy, social life and the investment processes in the city. It is in favour of many infrastructural investments undertaken by the city but its members believe that the city authorities should remain more assertive in negotiations with investors and focus should be placed on the local economy, as well as social policy and public utilities (GDA05).

The scale of their activity is varied depending on whether the subject being tackled covers either a street or a district. This can be exemplified by the project to redevelop the street Podwale Przedmiejskie in Gdańsk (GDA01). This road between two historic districts in Gdańsk was rebuilt into a major traffic artery in the 1950s and 1970s, becoming both a spatial and a mental barrier contributing to the decline and isolation of the Stare Przedmieście district. According to social surveys conducted during the project, the road constitutes a border of the historic city in the minds of residents and tourists. Therefore, a strategy to redevelop the road was discussed, with the participation of various stakeholders and with the cooperation of the Faculty of Architecture of Gdańsk University of Technology and the Polish Town Planners Association. The project was developed using the method of full participation, which involves a discussion between planning group members and their independent work on the best solution. This resulted in a design concept in which it was proposed to change the entire character of the road and to make it more accessible to pedestrians by decreasing the number of traffic lanes, complementing the existing buildings and creating new public and green spaces (FRAG 2018).

Sometimes the actions are not focused on a particular neighbourhood, but involve direct contact with the residents (GDA05). In all cases, different planning initiatives are undertaken. The associations protest against particular planning solutions proposed by the municipality, for example the expansion of the Baltic Gallery (Galeria Battycka) shopping mall or the regulation of the Strzyża Stream in Gdańsk (GDA05). Such protests are, however, unsuccessful in many cases (GDA05). There are many cases in which the opinions of residents and various associations are completely ignored by the planning office in Gdańsk. For example, all remarks regarding the local spatial development plan for the passenger hub area in Wrzeszcz were rejected (GDA04).

Moreover, attempts are made to persuade the city authorities to create local development plans based on full cooperation with urban activists and residents (GDA01). For example, thanks to the initiative of a member of the district council in Wrzeszcz Górny six plans were created (GDA04). And yet, in some cases pressure from urban activists is not enough to persuade the municipality to start a planning procedure, as was the case with the Gdańsk Shipyard area (GDA01). On the other hand, full and continuous cooperation with the city authorities is stressed by many members of urban movements, and was reported in many cases and at many levels of governmental structures (GDA01, GDA02)

Urban movements try to develop new participatory tools that could involve more residents in the process of urban governance, e.g. an experimental project called "Courtyards" was carried out by FRAG in cooperation with DoctorAnts - a research club of PhD students of the Gdańsk University of Technology -in which new modes of participation were tested. The project was aimed at creating model solutions for the redevelopment of courtyards in the quarters of the historic district of the city. When two model courtyards were developed, the project gained the interest of the municipal authorities and obtained funding that allowed the redevelopment of several courtyards to be completed (GDA01). The project employed an approach called "design thinking", which is defined as a hands-on, user-centric design thinking methodology. It consists of three major phases: understanding by conducting research to develop understanding of the issue and observing the user's problems; exploring by coming up with creative ideas and prototyping them; and, finally, materialising the project by testing, and obtaining feedback from the users and implementing it. The process, however, is not supposed to be linear, and each phase is meant to be iterative and cyclical in order to obtain the best results (Gibbons 2016).

Another very successful participatory project with the use of the aforementioned "place-making" approach was also carried out for the redevelopment of Świętopełka Park by the City Initiative association, where local residents took part in workshops and discussions to express their wishes regarding the common urban space. The project was started in 2015 with extensive consultations with the residents. As a result, the public space was redeveloped according to the needs of it users of all ages, and consisted of greenery, new infrastructure, a playground and new pedestrian routes (GDA02). The latter were created using the idea of "desired paths" whose layout is not pre-designed but is developed by observing and mapping the paths taken by the users (PMG 2016).

However, it was also noticed that people are interested in certain issues only when they are directly affected (GDA01, GDA03) or in case of very controversial issues, such as the decommunisation of street names, which was a widely discussed topic at the time of writing. This initiative was undertaken by the Polish government and it was aimed at changing the names of streets named after those active in the communist regime. However, it was very strongly opposed by many residents, due to the many inconveniences and official procedures it required. On the other hand, expert or ideological meetings always get a much smaller response (GDA05). The opinion was also stated that people who get involved in the presented initiatives are still a very small fraction of the population of Gdańsk (GDA03) and that the time to develop a participatory spirit is already over as its effectiveness is no longer believed in (GDA05).

During the interviews, the very interesting view was expressed that many urban activists are becoming increasingly interested in sitting on district councils, which have more authority in planning procedures. This increase in interest is also due to the fact that 
the threshold of votes required for district council elections was reduced. Consequently, some urban movements in Gdańsk are experiencing a significant loss of members to councils (GDA03). Moreover, the activity of urban movements is unprofitable. Only some of them, e.g. FRAG, that are institutionalised and have a permanent work programme are successful in obtaining some funding. In other cases, without proper financial support, they cannot be considered to have developed substantively and become a partner in local urban governance (GDA04).

\section{Urban activism in Gdynia}

Urban activism began later in Gdynia than in the previously discussed cities and is relatively the least developed. In Gdynia two different urban movements were interviewed: Cycling Gdynia (Rowerowa Gdynia), which is an expert organisation aiming to develop cycling-friendly infrastructure and to promote cycling in Gdynia (GDY02), and The Common City (Miasto Wspólne) which was established in response to the lack of an urban movement in the city to relay the needs of residents to the authorities (GDY01). They started their activity because of the city's lack of interest in its citizenry (GDY01), and because of a spatial and infrastructural disorder (GDY02). The scale of their actions is usually local and their planning activities are mostly focused on fundraising from the Participatory Budget (Budżet Obywatelski), which is a tool that allows residents to discuss and directly influence the process of decision making by proposing and voting for citizen's projects to be financed by public funding (WR 2018). They also submit comments on local spatial development plans. However, the members of The Common City expressed the view that the city authorities have a very negative attitude towards the changes proposed in these remarks.

Some public space projects in Gdynia have already been realised by The Common City association, e.g. the creation of a woonerf on Abrahama Street that received funding in the Participatory Budget (GDY01). A woonerf is a type of street that consists of traffic lanes, parking spaces and public space, with priority given to pedestrians and cyclists. The initial concept was consulted on with the residents and their suggestions were included in the final project, which was realised by the A2P2 Architecture \& Planning studio (Janowicz 2017).

By contrast, cooperation with the municipality is positively assessed by the members of Cycling Gdynia (GDY02). Urban activists in Gdynia noticed increased resident interest in the issue of public space. The most important form of public discussion still takes place in news and social media. However, many open meetings and events are also organised by The Common City association. (GDY01). The members of Cycling Gdynia do not get involved in public participation as they believe it is not an effective tool. Nevertheless, they organise some educational events and workshops for residents, e.g. a cycling school (GDY02).

\section{Conclusions and discussion}

Based on the collected materials, some preliminary conclusions on the characteristics of urban activism in the Tri-City and Poznań in regard to urban planning and social participation can be outlined. For example, many urban movements have become expertise and logistics groups promoting a certain set of spatial solutions (e.g. GDA01, GDY02, PZ04), while others focus primarily on political and social activities (GDA05) or on local activities aimed at improving the quality of public spaces (GDA02). No single, shared vision of the city or directions for its spatial development is expressed by the members of urban movements. Even at the level of individual organisations, opinions on these issues sometimes differ. During the interviews, the answers were mostly general: from the trend of new urbanism in the context of sustainable development (GDA01), through the concepts of a social city (GDA05), a city for its residents (GDY01), to the city as a community of interests and responsibility (PZO3) or a pedestrian city and a city of short distances (GDA02). Some references were also given to the European agendas and planning strategies, including the Leipzig Charter (European Commission 2007) (PZ04) and the European Charter for Equality (Council of European Municipalities and Regions 2006) (GDA05).

Most of the examined urban movements carry out various activities connected with local urban planning, formulating new concepts for spatial development, submitting critical remarks to local spatial development plans, taking actions to raise public awareness in many spatial issues, and promoting the spatial education or activation of residents. They carry out many initiatives at both the local and city-wide scale. They also come up with many innovative forms of promoting participatory planning, such as protests and happenings. It can be stated that, in the presented cities, urban movements are probably the most important actor in the development of inclusive spatial planning. However, the spatial consequences of these actions cannot be fully assessed, as the outcomes of the local planning acts to which they have contributed are to be implemented within the coming years. Therefore, careful observation and evaluation are required.

It can also be said that urban movements play a very important role in developing the process of participation. It is due to the actions of the urban movements that we are now observing the emergence of new, more advanced participatory tools, such as workshop participation or the technique of "protest management", which is intended to translate a certain resident attitude of protest into constructive actions in the city space (discussed by GDA03, PZ04). They have achieved expertise in this field and developed methods which allow conditions fostering dialogue to be created (PZ02). A certain mode of action was developed that helped people to communicate effectively and briefly, speaking only specifically on a particular matter (PZ01).

Moreover, urban movements have caused a change in the course of public debate on spatial and social issues. It was underlined in the interviews that, due to their initiatives, urban policy is no longer associated with centralistic planning but rather with Gehl's metaphor of "cities for people" (see Gehl 2014) and that it was noticed that the quality of urban space can be improved by a set of simple spatial and transportation solutions (PZO2). On the other hand, because concerning views were expressed during the interviews that urban activism continues to affect a narrow social group limited to members of the new middle class (PZ02) and that it is closed to the problems and interests of certain social groups (PZ03), the target group of these planning and participatory activities should be submitted to further, extensive studies. Perhaps, in the future, actions should be taken to involve more stakeholder groups in the phenomenon of urban activism.

Urban movements have developed various methods of cooperation with city authorities. These include meetings to discuss major projects, discussions with officials at various levels (GDA01) and submitting of comments and suggestions for local spatial development plans or on-going investments in the city. A change in attitude of the city authorities towards grassroots initiatives is not uniformly perceived by the city activists and social experts. Some of them state that the authorities are cooperating and mutually supporting each other's activities (PZ04, GDA01, GDA02, GDA05, GDY02). Their advanced knowledge is also connected with the process of local planning, which grants them a special creation and expert function, making them advisory groups to local authorities (PZ04, GDA01, GDA02, GDY02). However, there are still many cases where the proposals and demands of urban movements are ignored and sometimes the assessment of the dialogue with the city authorities is clearly 
negative (GDY01). Moreover, the view was expressed that there are two levels of this cooperation - one that concerns large investments, where there is a lot of money involved, and another that concerns mainly soft management of public space. At the first level virtually nothing has changed, and it is only at the second level that some sort of a partnership has developed (GDA04).

In Poznań many former urban activists are already members of the city council and the vice-president of the city in the 2014-2018 term (Maciej Wudarski) is a former member and the vice-chairman of The Right to the City association (PZO4). Nevertheless, an opinion was expressed that members of urban movements entering city council structures did not cause significant change. It is, rather, at the level of district councils that urban activists contribute to a change in priorities (PZO2). Therefore, it seems interesting that many urban movements' members decided to stand as candidates in this year's municipal elections (not only in Gdańsk and Poznań but also in many other Polish cities, e.g. Warsaw, Sopot, Zielona Góra, Świdnica or Torun. For further information see: Kongres Ruchów Miejskich 2018b). However, the result of the elections was not entirely successful for urban movements. In Poznań only two candidates from the Right to the City association will sit in the City Council. In Gdańsk, the A Better Gdańsk association received enough votes to cross the election threshold, although none of its members managed to become representatives in the City Council. On the other hand, according to Elżbieta Jachlewska, the former candidate for the president of Gdańsk, the pre-election campaign helped to promote many of the postulates of urban movements regarding, for example, urban infrastructure, greenery, housing or residents' right to the city (Szreter 2018). Moreover, the A Better Gdańsk association signed an agreement with the candidate for the president of Gdańsk, Paweł Adamowicz, who entered the second round of the elections, to implement some of their proposals if he won. These include, among many others, the issue of allowing the district councils with legislative initiative into the City Council (PMG 2018) which may provide them with a significantly stronger influence on urban politics. However, the outcomes of the decision of urban movements' members to develop political activity are yet to be observed and assessed.

It can be generally concluded that the phenomenon of urban activism in regard to urban planning and participation in the three studied cities is very complex and dynamic, and requires further research, including in the form of quantitative studies, if it is to be fully described. As the interviewed urban movements represent different profiles of their activity, this issue should be analysed and categorised in detail, including in the case of other associations that were not included in this study. It is important to note that the development of the body of knowledge and practical experience related to urban planning procedures and participation methods and to the functioning of transport infrastructure may be as important as the role of urban movements in the creation of a platform to exchange resident experiences and expectations regarding the quality of urban space (for example, in the form of discussion groups, meetings, debates and other events). Therefore, the aspect of initiating cooperation between various stakeholders also requires further examination.

A new form of urban activism is going beyond the local scale. In many countries, individual organisations and urban movements combine their efforts to move towards action at the urban, national or even international level (Martínez 2007; Martínez 2011). In Polish cities we can also observe such a phenomenon in the form of the Urban Movements Congress, which currently brings together 34 members from 16 Polish cities (Kongres Ruchów Miejskich 2018b). The congress is an important venue for organising and consolidating urban movements (Kowalewski 2013), and, as some representatives of the examined urban movements pointed out, it is also a platform for exchanging experiences to allow the effective resolution of local problems and a strong "polyphonic voice" in the public debate on issues, including at the national level, such as new legislative proposals (GDA03, PZ04). The opinion of the congress is more powerful in the public debate than the opinions of individual associations, multiplying mutual efforts, especially in legislative issues. The congress commented on many draft laws, e.g. on the new landscape act or the nature conservation act, although in these cases it was unsuccessful (GDA03).

The voice of urban movements is becoming increasingly noticeable in public discussion, and often they replace the city authorities in publicising many spatial problems, but they are still not a strong enough alternative to public institutions in the process of creating urban policy and spatial management. Their actions, although in many cases very effective on a local or urban scale, are still singular and too scattered to form a strong voice and ensure the role of urban movements as a stable partner in the development of urban policy. However, it may be stated that urban commons in Poland are undergoing a significant rehabilitation, responding to a lack of policies and legal instruments to ensure "the commonality of urban space". Nevertheless, a change should also follow in the approach of municipal authorities (Grabkowska 2018).

The conducted research was qualitative in character and the techniques used allowed the showcasing of the different aspects of the urban movements' activities in regard to local urban planning and participation. Although the group subjected to the study was varied, it is important to note that it was not the objective to collect statistical data on the activity of urban movements in Polish cities but, rather, to preliminarily determine this phenomenon and directions for further research. It seems especially important to continue the study, using both qualitative and quantitative techniques, in the context of the forthcoming municipal elections. If the members of urban movements are successful in obtaining positions among municipal authorities, it will be worth observing what impact their political activity will have on shaping spatial policy and the process of participation. If this becomes the case, urban movements will have to address completely new problems that affect European and Polish cities, such as security problems, migration or deteriorating environmental conditions (and smog in particular).

Annex 1. Instructions for free-form interviews. Source: own elaboration.

1. Inception and development of activities

- When did the movement begin its activity?

- Who was the founder of the movement?

- What was the reason for setting it up?

- What problems does the association deal with?

- Has the activity of the movement been related to spatial issues since its inception?

- How many members are there currently in the movement, and how many of them are related to architecture, urban planning or spatial planning?

- How has the activity of the movement developed in terms of its substantive background?

2. Operating profile

- What is the basic profile of the movement's activity?

- Does the movement have a fixed action agenda?

- What is the association's "vision of the city"?

- Does the movement present its ideas and concepts relating to urban space development to the public? If so, how? 
3. Range and mode of operation

- Is the movement institutionalised?

- Does the movement have regular recipients?

(a) is it a permanent group?

(b) how can it be characterised?

- Does the movement organise regular events (meetings, lectures or protests)?

- What initiatives does the movement take?
4. Cooperation with city authorities

- What is the attitude of the city to the movement's activity?

- Do the city authorities cooperate or did they cooperate with the movement?

- Does the movement criticise local plans? If yes, are the comments made acknowledged in further work on projects?

\section{References}

Babbie, E 2007, Badania społeczne w praktyce [The practice of social research]. Wydawnictwo Naukowe PWN [PWN Scientific Publishing], Warszawa.

Badach, J \& Dymnicka, M 2017, 'Concept of "Good Urban Governance" and Its Application in Sustainable Urban Planning', IOP Conference Series: Materials Science and Engineering, vol. 245, pp. 1-9.

Baranowski, A 2016, 'Przestrzeń obywatelska (nieopublikowany manuskrypt)' ['Civic space (unpublished manuscript)'].

Barber, B 2014, If Mayors Ruled the World: Dysfunctional Nations, Rising Cities. Yale University Press.

Boer, RWJ \& Vries, J De 2009,'The right to the city as a tool for urban social movements: The case of Barceloneta', in The 4th International Conference of the International Forum on Urbanism, pp.1321-1330

Coaffee, J \& Healey, P 2003, "“My Voice: My Place”: Tracking Transformations in Urban Governance', Urban Studies, vol. 40, no. 10, pp. 1979-1999.

Council of European Municipalities and Regions 2006, The European Charter for Equality of women and men in local life. Innsbruck.

DB 2018, Najważniejsze, że problemy, o których mówią ruchy miejskie zostały zauważone, Dziennik Bałtycki [Most importantly, the problems discussed by urban movements were noticed, Dziennik Bałtycki newspaper]. Available from: $<$ https://dziennikbaltycki.pl/najwazniejsze-ze-problemy-oktorych-mowia-ruchy-miejskie-zostaly-zauwazone/ar/13623 728? fbclid=IwAR1 po3zfCLOBabDHhC6bOa-wnTtmSiJRVT W2PTuRht4YdyrkGAznOutH4XY>. [28 October 2018].

Domaradzka, A \& Wijkström, F 2016, 'Game of the City Renegotiated: the Polish Urban Re-generation Movement as an Emerging Actor in a Strategic Action Field', Polish Sociological Review, vol. 3, no. 195, pp. 291-308.

European Commission 2007, Leipzig Charter on European Sustainable Cities. Leipzig.

FRAG 2018, Podwale Przedmiejskie, Forum Rozwoju Aglomeracji Gdańskiej [Podwale Street, The Gdańsk Agglomeration Development Forum]. Available from: <https://frag.org.pl/ portfolio/podwaleprzedmiejskie/>. [28 October 2018].

García, M 2006, 'Citizenship Practices and Urban Governance in European Cities', Urban Studies, vol. 43, no. 4, pp. 745-765.

Gehl, J 2014, Miasta dla ludzi [Cities for people]. Wydawnictwo RAM [RAM Publishing], Kraków.

GMM 2018, Ulica Abrahama - pierwszy gdyński woonerf, Gdynia - moje miasto [Abrahama Street - first woonerf in Gdynia, Gdynia - my city]. Available from: <https://www.gdynia.pl/ co-nowego,2774/przebudowa-ulicy-abrahama,501634. [28 October 2018]>.

Grabkowska, M 2018, 'Urban space as a commons in print media discourse in Poland after 1989', Cities, vol. 72, no. August 2017, pp. 122-129.
GW 2018, Poznań: Władze miasta przejmują stadion im. Edmunda Szyca na Dolnej Wildzie! Udało się osiągnąć porozumienie!, Głos Wielkopolski [Poznań: municipal authority has reclaimed the Edmund Szyc stadium in Dolna Wilda! An agreement has been reached, Głos Wielkopolski newspaper]. Available from: <https://gloswielkopolski.pl/ poznan-wladze-miasta-przejmuja-stadion-im-edmundaszyca-na-dolnej-wildzie-udalo-sie-osiagnac-porozumienie/ ar/13356156>. [28 October 2018].

GWP 2016, Co stanie na Sołaczu? Specjaliści od przestrzeni źle oceniają plan dla tej dzielnicy, Gazeta Wyborcza Poznań [What will happen to Sołacz? Spatial planning experts assess the district development plan to be poorly designed, Gazeta Wyborcza Poznań newspaper]. Available from: $<$ http://poznan.wyborcza.pl/poznan/1,36001,20982009,costanie-na-solaczu-specjalisci-od-przestrzeni-zle-oceniaja. html?disableRedirects=true>. [28 October 2018].

Isin, EF 2009, 'Citizenship in flux: The figure of the activist citizen', Subjectivity, vol. 29, no. 1, pp. 367-388.

Jacobsson, K 2015,'Introduction: the Development of Urban Movements in Central and Eastern Europe', in K Jacobsson (ed), Urban Grassroots Movements in Central and Eastern Europe, pp.1-32. Ashgate Publishing, London.

Katz, B \& Nowak, J 2017, The New Localism: How Cities Can Thrive in the Age of Populism. The Brookings Institution, Washington, D.C.

Konecki, TK 2005, Studia z metodologii badań jakościowych. Teoria ugruntowana [Qualitative research methodology. Established theory]. Wydawnictwo Naukowe PWN [PWN Scientific Publishing], Warszawa.

Kongres Ruchów Miejskich 2018a, 15 TEZ O MIEŚCIE Kongresu Ruchów Miejskich [15 Urban Theses of the Congress of Urban Movements]. Available from: <https:// kongresruchowmiejskich.pl/15-tez-o-miescie-kongresuruchow-miejskich/>. [1 June 2018].

Kongres Ruchów Miejskich 2018b, Kongres Ruchów Miejskich [Congress of Urban Movements]. Available from: <https:// kongresruchowmiejskich.pl/>. [15 September 2017].

Kowalewski, M 2013, 'Organizowanie miejskiego aktywizmu w Polsce: Kongres Ruchów Miejskich' [Organising urban activism in Poland: Congress of Urban Movements], Social Space Journal, vol. 6, no. 2, pp. 99-126.

Kowalewski, M 2016, Protest miejski. Przestrzenie, tożsamość i praktyki niezadowolonych obywateli miast [Urban protest. Spaces, identity and practices of the dissatisfied citizens]. NOMOS, Kraków.

Lefebvre, H 1967, La droit à la ville. Anthropos, Paris.

Leontidou, L 2006, 'Urban social movements: From the "right to the city" to transnational spatialities and flaneur activists: Introduction', City, vol. 10, no. 3, pp. 259-268. 
Lewandowska, I 2004, 'Wywiad jako technika zdobywania informacji źródłowych w badaniu historii najnowszej' ['Interview as a form of collecting information in the recent history research], Echa Przeszłości [Echoes of the past], vol. 5, pp. 279-299.

Martínez, M 2007, 'The Squatters' Movement: Urban CounterCulture and Alter-Globalization Dynamics', South European Society and Politics, vol. 12, no. 3, pp. 379-398.

Martínez, M 2011, 'The Citizen Participation of Urban Movements in Spatial Planning: A Comparison between Vigo and Porto', International Journal of Urban and Regional Research, vol. 35 , no. 1, pp. 147-171.

Mayer, M 2013, 'First world urban activism: Beyond austerity urbanism and creative city politics', City, vol. 17, no. 1, pp. 5-19.

McClymont, K \& O'Hare, P 2008, "We're not NIMBYs!" Contrasting local protest groups with idealised conceptions of sustainable communities', Local Environment, vol. 13, no. 4, pp. 321-335.

Mergler, L, Pobłocki, K, \& Wudarski, M 2013, Anty-Bezradnik przestrzenny - prawo do miasta $w$ działaniu [Spatial antihelpless - the right to the city in action]. Res Publica Nowa.

Monno, V 2016, 'Activism and urban politics to come: escaping the acceptability trap', City, Territory and Architecture, vol. 3, no. 25 , pp. $1-8$.

NN/g 2018, Design Thinking, Nielsen Norman Group. Available from: <https://www.nngroup.com/articles/design-thinking/>. [28 October 2018].

Novy, J \& Colomb, C 2013, 'Struggling for the Right to the (Creative) City in Berlin and Hamburg: New Urban Social Movements, New "Spaces of Hope"?', International Journal of Urban and Regional Research, vol. 37, no. 5, pp. 18161838.

Nowa Głogowska [New głogowska Street] 2018. Available from: <http://nowaglogowska.pl/>. [1 June 2018].

Pickvance, CG 2003, 'From urban social movements to urban movements: a review and introduction to a symposium on urban movements', International Journal of Urban and Regional Research, vol. 27, no. March, pp. 102-109.

Pluciński, P 2013, 'Miejskie (r)ewolucje. Radykalizm retoryki a praktyka reformy' ['Urban (re)volution. The radicalism of rhetorics and the practice of reform'], Praktyka teoretyczna, vol. 3, no. 9, pp. 133-157.

Pluciński, P 2014, '„Miasto to nie firma!” Dylematy i tożsamość polityczna miejskich ruchów społecznych we współczesnej Polsce' ["The city is not a company!" the dilemmas and identity of social urban movements in contemporary Poland'], Przegląd Socjologiczny [Sociological Review], vol. 63, no. 1, pp. 137-170.

PMG 2016, Park Świętopełka po nowemu! [Świętopełk's Park Anew!], Portal Miasta Gdańska [The Porthal of the City of Gdańsk]. Available from: <https://www.gdansk.pl/urzadmiejski/prasa/park-swietopelka-po-nowemu,a,66798>. [28 October 2018].

PMG 2018, WYBORY. "Lepszy Gdańsk" i Elżbieta Jachlewska: - Głosujmy na Adamowicza [ELECTIONS. "Better Gdańsk" and Elżbieta Jachlewska: - Let us vote for Adamowicz], Portal Miasta Gdańska [The Portal of the City of Gdańsk]. Available from: <https://www.gdansk.pl/wiadomosci/ wybory-lepszy-gdansk-i-elzbieta-jachlewska-glosujmy-naadamowicza,a,128868>. [28 October 2018].

Polanska, D V. 2018, 'Going against institutionalization: New forms of urban activism in Poland', Journal of Urban Affairs, pp. 1-12.

PPS 2018, PPS, Project for Public Spaces. Available from: $<$ https://www.pps.org/>. [28 October 2018].
Rosochacka, A 2017,'Rozmowa z Markiem Piekarskim'['A conversation with Marek Piekarski], in M Praczyk (ed), Poznań w działaniu. Społeczne inicjatywy dawniej i dziś [Poznań at work. Social initiatives past and prersent]. Stowarzyszenie czas kultury [The Time for Culture Association], Poznań.

de Souza, ML 2006, 'Social movements as "critical urban planning" agents', City, vol. 10, no. 3, pp. 327-342.

Sowada, T \& Kotus, J 2015, Rola stowarzyszeń lokalnych w procesie partycypacji społecznej w zarządzaniu miastem. Przykład Poznania [The role of local associations in the process of social participation in city management. An example of Poznań]. Bogucki Wydawnictwo Naukowe, Poznań.

Stahre, U 2004, 'City in change: Globalization, local politics and urban movements in contemporary Stockholm', International Journal of Urban and Regional Research, vol. 28, no. 1, pp. 68-85.

Swerts, T 2017, 'Creating Space For Citizenship: The Liminal Politics of Undocumented Activism', International Journal of Urban and Regional Research, vol. 41, no. 3, pp. 379-395.

WR 2018, Wrocławski Budżet Obywatelski, Wrocław Rozmawia [Wrocław's Citizen Budget. Wrocław Deliberates]. Available from: <https://www.wroclaw.pl/rozmawia/wroclawskibudzet-obywatelski-definicja>. [28 October 2018]. 